\title{
ガス圧焼結窒化ケイ素のき裂進展挙動
}

\author{
飯尾 聡・丹羽倫規・多島 容・渡辺正一 \\ 日本特殊陶業(株)中央研究所, 485 小牧市大字岩崎 2808
}

\section{Crack Propagation Behavior in Gas Pressure Sintered Silicon Nitride}

Satoshi IIO, Tomonori NIWA, Yo TAJIMA and Masakazu WATANABE

$R \& D$ Center, NTK Technical Ceramics, NGK Spark Plug Co., Ltd., 2808, Iwasaki, Komaki-shi

485

[Received May 30, 1991; Accepted November 21, 1991]

\begin{abstract}
The crack propagation behavior in gas pressure sintered $\mathrm{Si}_{3} \mathrm{~N}_{4}$ was investigated under cyclic and static loading by 3-point bending for pre-cracked specimens by indentation on the center of the mirror finished tensile surfaces. Crack propagation occurred under cyclic loading with a maximum applied stress below the applied stress at which crack propagation stagnated under static loading, showing that crack propagation velocity under cyclic loading was higher than that under static loading. Although intergranular crack propagation with crack-bridging was observed in both cases under cyclic and static loading, crack-bridging, observed after static loading, was found to be fractured by the subsequent cyclic loading. It was thought that the crack shielding force by crack-bridging, which is effective for restraining crack propagation under static loading, was decreased by cyclic loading, resulting in faster crack propagation under cyclic loading than under static loading.
\end{abstract}

Key-words : Silicon nitride, Cyclic fatigue, Static fatigue, Pre-cracked specimen, Residual stress

\section{1. 緒 言}

近年, 窒化ケイ素のエンジン部品, 産業用部品などへの 応用が進められているが1)，構造部品として窒化ケイ素を 使用する際にはその疲労特性を把握することが重要であ る. 窒化ケイ素の疲労に関しては種々の試験片形状, 試験 条件での研究が行われており，予き裂のない試験片につい ては時間依存型の疲労挙動を示すことや2),3)，応力比の影 響を受けることなどが報告されている(4) 6)，一方，予き 裂を有する試験片については繰り返しの影響があることが 確認されており7) 14)，それに与える予き裂長さの影響な ぞも検討されている11),12).

著者らはこれまでにガス圧焼結窒化ケイ素を試料とし て, 室温大気中に拈ける疲労挙動に与える予き裂長さ, 周 波数, 応力比の影響等を調查し, 予き裂のない試験片では 静疲労寿命と繰り返し疲労寿命は時間で整理できる時間依 存型の疲労挙動, 予き裂のある試験片では繰り返し数依存 型の疲労挙動で, 繰り返し疲労寿命が静疲労寿命に比べて 明らかに短くなること等を報告した2),14).

本研究では, 予き裂を導入した試験片を用いて, 疲労寿 命を決定するき裂進展速度を直接測定すること，及び，き
裂進展状況の観察によりき裂進展メカニズムを解明し, 繰 り返し疲労と静疲労で寿命が異なる理由を明らかにするこ とを試みた。

\section{2. 実験方法}

実験に供した窒化ケイ素は, 焼結助剂として $\mathrm{Al}_{2} \mathrm{O}_{3}$ 及 び $\mathrm{Y}_{2} \mathrm{O}_{3}$ を添加したガス圧焼結窒化ケイ素であり, その特 性を表 1 に示す.

上記窒化ケイ素を 140 番のダイヤモンド砥石を用いて研 削加工することにより，JIS R 1601 に基づく形状 $(3 \times 4 \times 40 \mathrm{~mm})$ の試験片を作製した．得られた試験片の 引張面（ $4 \times 40 \mathrm{~mm}$ の面）を鏡面仕上げし，その中央部に $49 \mathrm{~N}$ の荷重でビッカース圧子を圧入して予き裂（予き裂 長さ $2 c \fallingdotseq 180 \mu \mathrm{m})$ を導入した.

上記の予き裂入り試験片に対して, 室温大気中で油圧 サーボ式疲労試験機を用いて, スパン $30 \mathrm{~mm} の 3$ 点曲げ により静荷重あるいは繰り返し荷重を負荷することにより 疲労試験を行った. 繰り返し疲労試験は, 周波数 $10 \mathrm{~Hz}$, 応力比 $(R) 0.1$ の正弦波波形で行った.

進展して行くき裂の表面長さは試験を一時中断し, 光学 顕微鏡を用いて 400 倍の倍率で測定した。 また, 静荷重下 及び繰り返し荷重下で進展した表面き裂の様子を走査型電 子顕微鏡（SEM）により詳細に観察した.

\section{3. 結果及び考察}

図 1 に最大負荷応力 $228 \mathrm{MPa}$ で繰り返し荷重を加えた ときの繰り返し数 $(N)$ と表面き裂長さ $(2 c)$ の関係を 示す. き裂は, 最初荷重の繰り返しに伴い急速に進展し, 次いで徐々にき裂進展量が減少し, 再びき裂進展量が増加 し破断直前には急速なき裂進展が生じていることが分か る.このグラフ上の各点を滑らかな曲線で近似し, 任意の

Table 1. Properties of gas pressure sintered silicon nitride (GPSSN).

\begin{tabular}{|c|c|c|c|c|c|}
\hline $\begin{array}{l}\text { Density } \\
\left(\mathrm{g} / \mathrm{cm}^{3}\right)\end{array}$ & $\begin{array}{l}\text { Young's } \\
\text { Modulus } \\
\text { (GPa) }\end{array}$ & $\begin{array}{c}\text { Vickers } \\
\text { Hardness } \\
(G P a)\end{array}$ & $\begin{array}{l}\text { Fracture } \\
\text { Toughness } \\
\text { by SEPB } \\
\left(\mathrm{MPa} \cdot \mathrm{m}^{1 / 2}\right)\end{array}$ & $\begin{array}{l}\text { Thermal } \\
\text { Expansion } \\
\text { Coefficient } \\
\text { ( /K) }\end{array}$ & $\begin{array}{l}\text { Therma1 } \\
\text { Conductivity } \\
(W / m \cdot K)\end{array}$ \\
\hline 3.23 & 320 & 14.3 & 6.0 & $\begin{array}{c}2.8 \times 10^{-6} \\
\left.\text { (r.t. }-800^{\circ} \mathrm{C}\right)\end{array}$ & 27 \\
\hline
\end{tabular}




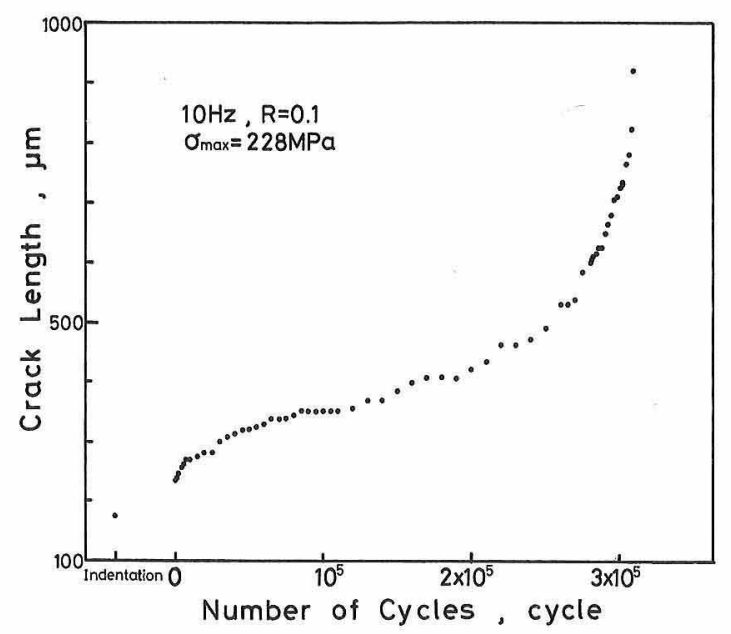

Fig. 1. Crack propagation curve under cyclic loading at 228 $\mathrm{MPa}(10 \mathrm{~Hz}, R=0.1)$.

き裂長さでその曲線に対して接線を引くと, その勾配から き裂進展速度 $(V=\mathrm{d} c / \mathrm{d} N)$ を求めることができる13)。一 方, 応力拡大係数については, 本研究ではビッカース圧子 打ち込みによりき裂を導入しているため，そのときの塑性 的変形によって生じる引張残留応力を考慮する必要があ り, 表面き裂先端の最大応力拡大係数 $\left(K_{\mathrm{I} \text { max }}\right)$ はビッカー 又打ち込反による残留応力項 $\left(K_{\mathrm{r}}\right)$ と負荷応力項 $\left(K_{\mathrm{s}}\right)$ の和で与えられる． $K_{\mathrm{r}}$ に関しては, Anstis らにより(1) 式で表されることが報告されている15).

$$
\begin{aligned}
& K_{\mathrm{r}}=\chi(\mathrm{E} / \mathrm{H})^{1 / 2} P / c^{3 / 2} \\
& \chi: \text { 定数 } \\
& E: \text { ヤング率 } \\
& H: \text { ビッカース硬度 } \\
& P: \text { ビッカース打ち込み荷重 } \\
& c: \text { 表面き裂長さの半長 }
\end{aligned}
$$

$K_{\mathrm{s}}$ に関しては, き裂形状が半円あるいは半楕円状である ならば Raju-Newman の解16)を用いて曲げ応力 $\left(\sigma_{\max }\right)$ が 負荷されているときの表面に括けるき裂先端の $K_{\mathrm{s}}$ を求め ることができる。本研究においては, き裂進展中の表面き 裂長さだけが測定可能で，き裂深さ（a）を測定すること はできない，繰り返し荷重負荷後に試料を即時破断させ， 破断面のSEM 観察を行ったところ, 図 2 に示したよう に, 繰り返し荷重により進展したき裂の最終時点のアスペ クト比 $(a / c)$ は0.68であることが観察された。 そこで, 初期き裂はアスペクト比が 1 の半円状き裂で, き裂進展 に伴ってき裂形状は半楕円状に変化し，そのときのアスペ クト比は初期き裂から最終き裂をで直線的に変化すると仮

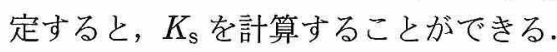

上述の方法により, 図 1 の結果加ら, 最大応力拡大係 数一き裂進展速度線図 $\left(K_{\mathrm{I} \text { max }}-V\right.$ 線図) を求めた結果を図 3 k示す．残留応力を無視すると $\left(K_{\mathrm{r}}=0\right)$ ，図 3 中に 印で示したように $\mathrm{V}$ 字形の $K_{\mathrm{I} \text { max }}-V$ 線図が得られた。こ れは初期き裂の状態では $K_{\mathrm{s}}$ よりも $K_{\mathrm{r}}$ の影響が大きく, き裂進展に伴い, 残留応力の影響が小さくなるためと考え

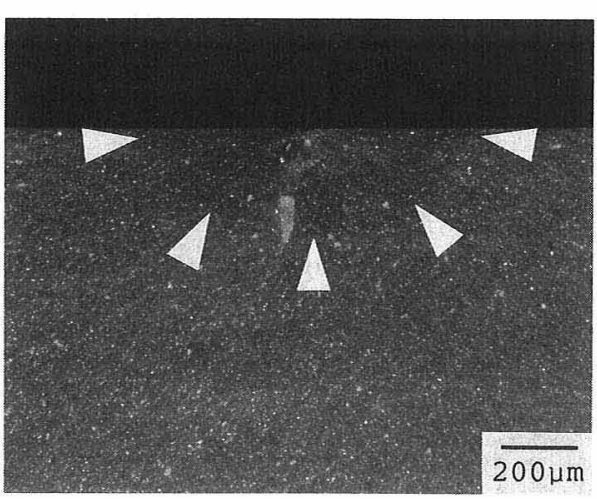

Fig. 2. SEM picture of fracture surface of specimen fast fractured after cyclic loading test at $228 \mathrm{MPa}$.

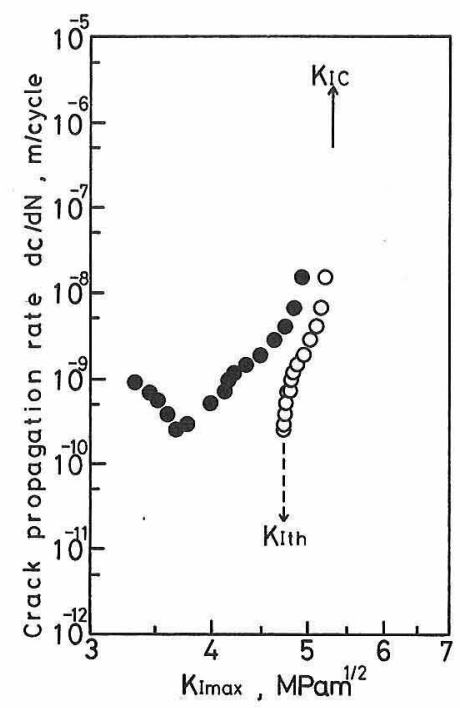

Fig. 3. $K_{\operatorname{Imax}^{-}} V$ diagram obtained by cyclic loading test.

られる，き裂進展速度と応力桩大係数は，き裂進展に伴う き裂進展抵抗の変化がないならば 1 対 1 に対応する，す なわち， $K_{\mathrm{I} \text { max }}-V$ 線図が一本の線になるはずである。そ こで以下の方法により(1)式に扑るるの值を決定した. 上述の $\mathrm{V}$ 字形の $K_{\mathrm{I} \text { max }}-\mathrm{V}$ 線図に扔いてき裂進展速度が最 小となっているデータ点（最小点）よりも $K_{\mathrm{I} \max }$ が小さ いデータ点の一つを選び, その点のき裂進展速度を挟ん で, かつ, 最む近いき裂進展速度を有する 2 点を最小点 よりも $K_{\mathrm{I} \max }$ が大きいデータ点の中から選択し, 直線近 似を行うと同じき裂進展速度に対して二つの $K_{\text {I max }}$ が求 まる.これらの差を， $\chi$ を変化させながら，最小点よりも $K_{\text {I max }}$ が小さいデータ点の各々について求め, その絶対值 の総和が最小になるように $\chi$ の值を決定した．このよう にして残留応力を考慮して求めた $K_{\text {I } \max }-V$ 線図を図 3 中 に○印で示す.このときの $\chi$ は0.011であり, Anstis らが 種々のセラミックス材料の実験結果を基に報告している值

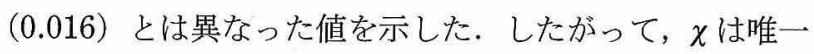
性のある定数ではなく, 材料の種類や実験方法等によって 異なった值を示す可能性がある. 残留応力を考虑すると, 
本実験では $K_{\mathrm{I} \text { max }}$ が $4.7 \sim 5.2 \mathrm{MPa} \cdot \mathrm{m}^{1 / 2}$ の範囲，き裂進展 速度が $2.5 \times 10^{-10} \sim 2 \times 10^{-8} \mathrm{~m} /$ cycle の範囲の $K_{\text {I } \max }-V$ 線 図を測定できたことになる，得られた $K_{\mathrm{I} \text { max }}-V$ 線図は逆 $\mathrm{S}$ 字曲線をしており，き裂が進展するための $K_{\mathrm{I} \text { max }}$ のしき い値 $\left(K_{\mathrm{I} \text { th }}\right)$ が存在するように思われた.この結果は, ラ プチャー試験により得られた逆 $\mathrm{S}$ 字形の最大応力一破断時 間線図 $(S-T \text { 線図 })^{14)}$ 之類似の傾向であった。これらの結 果は，き裂進展速度と寿命というアプローチの違いはある ものの, 疲労特性として良く対応していると考えられた。 本実験のき裂進展特性の測定結果はき裂の進展に伴ってそ のアスペクト比が直線的に変化するとの仮定に基づくもの であり, 今後実際のき裂のアスペクト比変化を何らかの方 法で確認する必要がある等の問題点を残しているが，ラプ チャ一試験に比べて少ない試験片数でかつ短時間に疲労寿 命評価を行える可能性のあることが分かった，なお，図 3 中に示した $K_{\mathrm{IC}}$ 值 $\left(5.3 \mathrm{MPa} \cdot \mathrm{m}^{1 / 2}\right)$ はこの試験片を即時 破断させ，その破壊応力を用いて上述の応力拡大係数の計 算方法に従って求めたものであり, SEPB 法を用いて測定 した $K_{\mathrm{IC}}$ 值 $\left(6 \mathrm{MPa} \cdot \mathrm{m}^{1 / 2}\right)$ よりも小さい值となった.

図 4 に287 MPa の応力で静荷重を負荷したときの荷重 負荷時間 $(t)$ と表面き裂長さの関係を示す. 静荷重下で も繰り返し荷重下と同様に最初き裂は急速に進展し, 次第 にき裂進展量が減少したが，その後き裂は急速に進展して 破断に至ってしまった．このき裂進展曲線よりき裂進展速 度 $(V=\mathrm{d} c / \mathrm{d} t)$ を求め, 上述の繰り返し荷重下の場合と 同様に $K_{\text {I } \max }-V$ 線図を求めた結果を図 5 （○印）に示す. なお, 残留応力項の計算には繰り返し荷重下の場合と同じ $\chi$ の值を用いた。 また, 繰り返し試験の結果を, 単純に 10 cycle が $1 \mathrm{~s}$ として時間基準のき裂進展速度に変換し, 同図中にプロット（・印）した. 図から明らかなように, 同じき裂進展速度を与える $K_{\mathrm{I} \text { max }}$ の值は繰り返し荷重下 の方が静荷重下に比べて小さい，すなわち繰り返し荷重下 では明らかに静荷重下よりもき裂が進展しやすいことが分 かる. 加えて, 繰り返し荷重下では $K_{\mathrm{I} \text { max }}$ の働く有効時 間は実際の荷重負荷時間よりもかなり短く，したがって， その差は更に大きいものと考えられる．また，静荷重下で

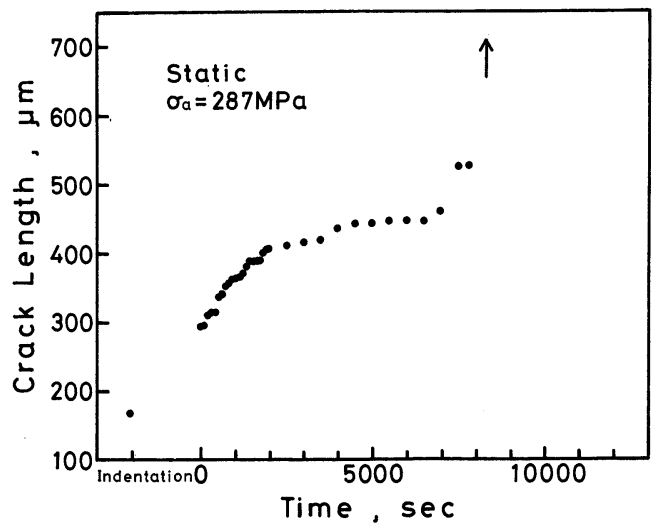

Fig. 4. Crack propagation curve under static loading at 287 $\mathrm{MPa}$.
は測定した領域内ではき裂の進展に伴い $K_{\text {I max }}$ が大きく なるとき裂進展速度が遅くなるように計算された。これ は, 静荷重下と繰り返し荷重下のき裂進展のメカニズムの 差によって生じているものと考えられる.

静荷重下と繰り返し荷重下のき裂進展速度を直接比較す るために，一本の試験片を用いて，最初負荷応力 245 $\mathrm{MPa}$ で静荷重を加え, その後に最大負荷応力 $199 \mathrm{MPa}$ で 繰り返し荷重を加えたときの荷重負荷時間あるいは繰り返 し数と表面き裂長さの関係を図 6 に示す．静荷重下では表 面き裂長さが約 $400 \mu \mathrm{m}$ で停留したが，その後 $199 \mathrm{MPa}$ と いう静荷重下よりも低い最大負荷応力の繰り返し荷重下で は比較的短時間でき裂が急速に進展することが観察され， Horibe の報告13) と同様, 繰り返し荷重下では静荷重下よ りも明らかにき裂が速く進展することが確認された。

繰り返しによる疲労の加速現象のメカニズムとしては, き裂先端における非線形プロセスゾーンの影響17)，材料 に内在する残留応力の影響18)，き裂面の不整合 (Indentation 損傷18)，結晶粒破片のかみ込み10)）等が提唱されて いるが，静荷重下及び繰り返し荷重下の疲労試験の結 果14)ではこれらの仮説を裏付ける結果は得られていない.

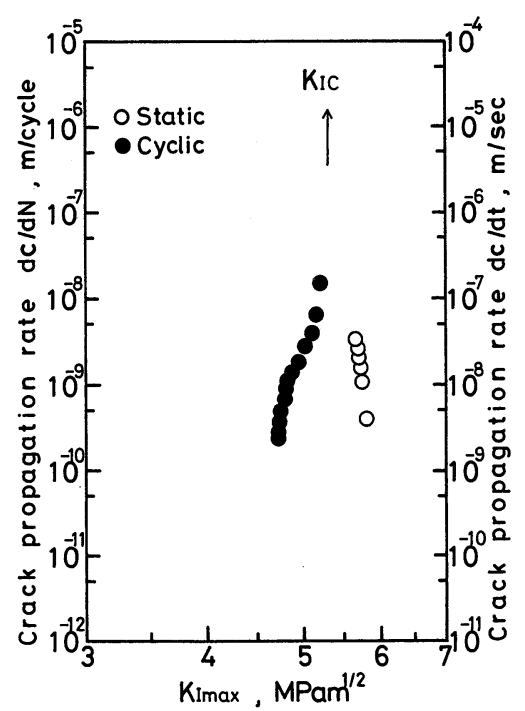

Fig. 5. $\quad K_{\operatorname{Imax}}-V$ diagram obtained by static loading test, compared with $K_{\text {Imax }}-V$ diagram obtained by cyclic loading.

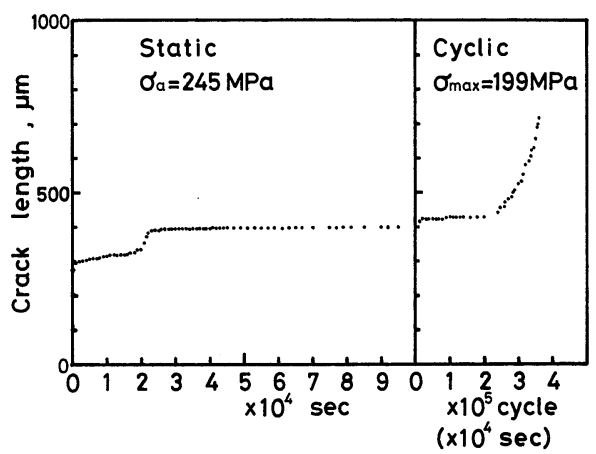

Fig. 6. Crack propagation curve under static loading at 245 $\mathrm{MPa}$ and subsequent cyclic loading at $199 \mathrm{MPa}$. 
静荷重下と繰り返し荷重下のき裂進展メカニズムの差を明 らかにするために，図6に示した試料に対して，静荷重 負荷後と繰り返し荷重負荷後のき裂をSEMにより観察 し，き裂進展状況の比較を行った. 図 7 に観察部位の模式 図を示し, 静荷重負荷後の A 点及び B 点の様子と, 繰り 返し荷重負荷後の $\mathrm{A}$ 点， $\mathrm{B}$ 点及び $\mathrm{C}$ 点の様子をそれぞれ 図 8 及び図 9 に示す。

静荷重下では，主に粒界破壞によりき裂が進展して抒 り，き裂先端のかなりの領域（30 $\mu \mathrm{m}$ 以上）に拈いてき 裂の不連続部分が観察された．屯た，粒子架橋が起こって

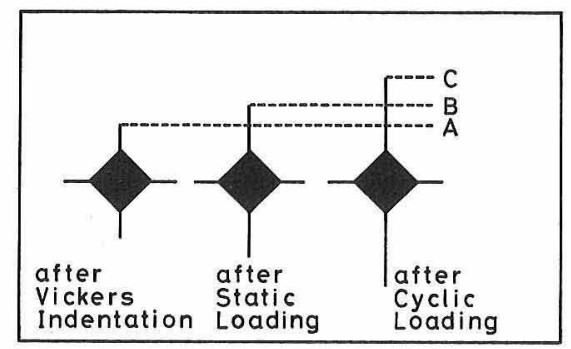

Fig. 7. Schematic of SEM observation positions of surface crack in the sample to which static and subsequent cyclic loading were applied.
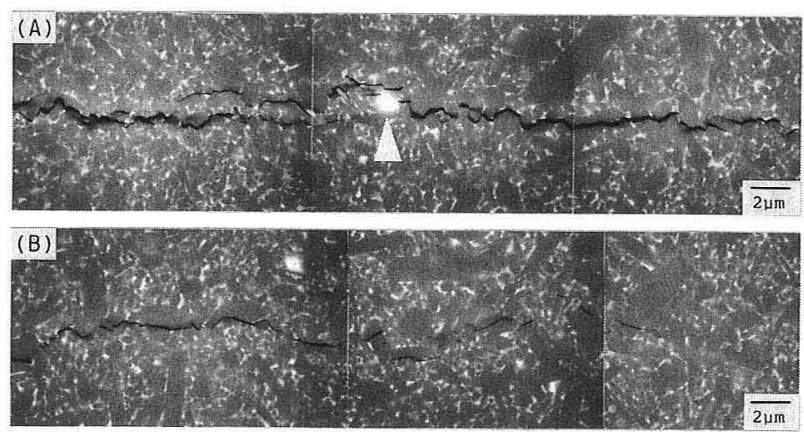

Fig. 8. SEM pictures of point $A$ and point $B$ in Fig. 7 after static loading.
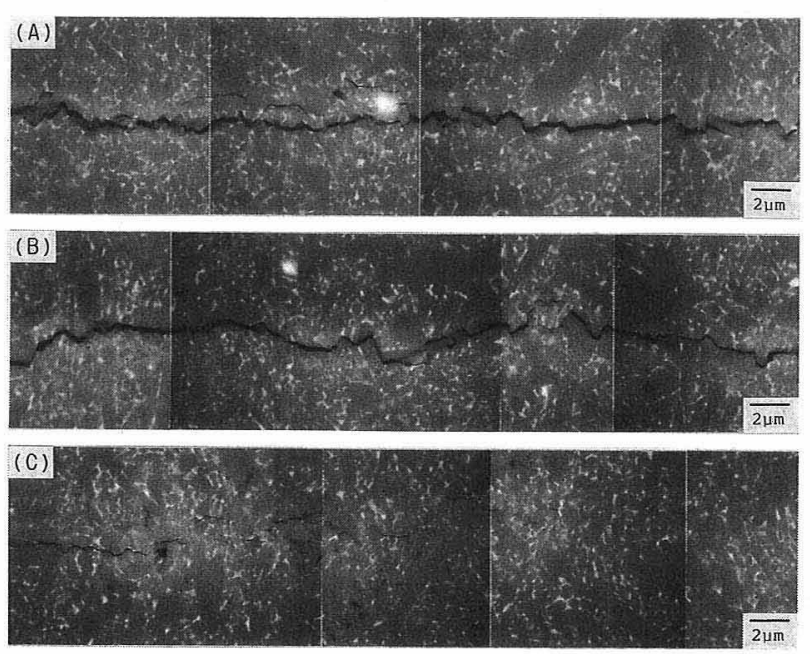

Fig. 9. SEM pictures of point $A$, point $B$ and point $C$ in Fig. 7 after static and subsequent cyclic loading.
いるところも多く観察され，その領域はき裂先端から80 $\mu \mathrm{m}$ 離れたところにまでも及んでいた，な扔，図 8 中に 矢印で示した白い組織の部分でき裂が分岐している様子が 観察されるが，これは金属不純物粒子であり，その周りに 特異な応力場が発生してき裂進展を妨げているものと考え られる。

繰り返し荷重下では，静荷重下と同様に主に粒界破壊に よりき裂が進展しているが，静荷重負荷後にき裂が不連続 になっていた部分や粒子架橋を生じていた部分が破壊さ れ，き裂が連結している様子が観察された。また，き裂先 端部分では, 静荷重下の場合と同様に，かなりの領域にき 裂の不連続部分や，粒子架橋が観察された。

以上の結果から，静荷重下と繰り返し荷重下に拈けるク ラック進展メカニズムの違いを考察し，図10に模式図で示 した．静荷重の楊合，き裂に負荷応力以外の力が働いてい なければ，き裂先端では負荷応力による応力拡大係数 $\left(K_{\text {app }}\right)$ がそのまま働き, 静荷重下のき裂の応力拡大係数 $\left(K_{\text {static }}\right)$ は $K_{\text {static }}=K_{\text {app }}$ となる．ところがき裂の不連続部 分や粒子架橋の存在が SEM により観察されていることか ら, き裂の遮蔽効果 $\left(\Delta K_{\text {static }}\right)$ がクラックウェイクの領 域で働き，き裂先端には $K_{\text {app }}$ よりも小さい $K_{\text {static }}=K_{\text {app }}$ - $\Delta K_{\text {static }}$ が働くことになる. 一方, 繰り返し荷重下では, 静荷重下でき裂が進展したときに生じていたき裂の不連続 部分や粒子架橋が破懐されながらき裂が進展する様子が SEM 観察で確認されたことから，き裂の不連続部分や粒 子架橋部分の粒子の結合力が繰り返し荷重により低下し て, その結果, き裂遮蔽効果 $\left(\Delta K_{\text {cyclic }}\right)$ が著しく小さく なっているものと考えられる $\left(\Delta K_{\text {cyclic }} \ll \Delta K_{\text {static }}\right)$. その結 果, 繰り返し荷重下におけるき裂先端の $K$ 值が静荷重下 に比べて大きくなり $\left(K_{\text {cyclic }}>K_{\text {static }}\right)$, 繰り返し荷重下の き裂進展速度が静荷重下のき裂進展速度よりも速くなった ものと考えられる.なお，この説明は図 3 に示した破壊 勒性值が SEPB 法で求めた值よりも小さい結果となった こととも矛盾しない.すなわち, SEPB法においてポップ インにより導入された予き裂には粒子架橋が存在してい て，繰り返し荷重により導入されたき裂の昜合よりも高い き裂進展抵抗を示したものと解釈される。

Maniette らはガス圧焼結窒化ケイ素のR カーブ挙動を

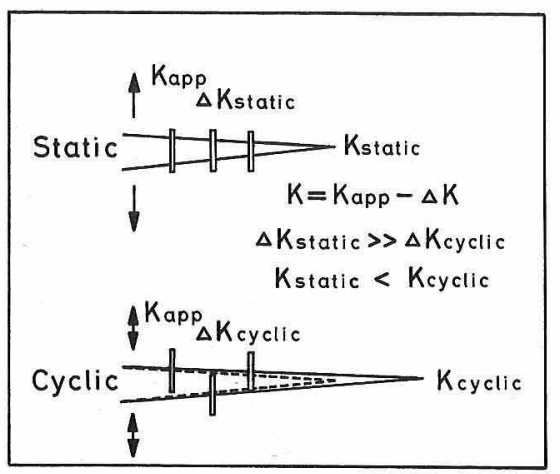

Fig. 10. Schematic of difference of crack propagation mechanisms under static and cyclic loadings. 
コンパクトテンション試験片を用いて測定し，上昇型の $R$ カーブ挙動で, $1 \mathrm{~mm}$ 程度の遷移領域が存在することを 確認している19)。本研究で用いた試料は試験片形状やき 裂形状が異なっているものの，静荷重下ではき裂先端から $80 \mu \mathrm{m}$ 程度離れた領域においても粒子架橋が観察されて いることから，同様に $R$ カーブ挙動を示していると考え られる，そして図 5 に示したように，繰り返し荷重下と 静荷重下で測定した $K_{\mathrm{I} \text { max }}-V$ 線図が異なり，静荷重下で はき裂進展に伴いき裂進展速度が遅くなる挙動が観察され たのは, 静荷重下と繰り返し荷重下では $R$ カーブ挙動が 異なっており, 静荷重下の方がき裂進展に伴うき裂進展抵 抗の上昇が大きく, き裂進展に伴って増大する負荷応力に よる $K_{\mathrm{I} \text { max }}$ の増大よりも上回ったためと推察される.

上述のき裂進展状況は表面き裂を観察したものであり内 部のき裂状態をでは明らかにはなっていない。しかし, 静 疲労後と繰り返し疲労後の破断面を観察した結果, 両者の

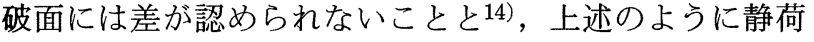
重下と繰り返し荷重下でき裂進展経路に差がないことを併 せて考えると，焼結体内部でも表面と同様な過程でき裂が 進展しているものと考えられる.

以上の結果から, 粒子架橋により高勒性化されている材 料は繰り返し荷重下での疲労劣化を受けやすいと考えら れ, 今後, 高勒性化と繰り返し疲労抵抗向上を両立させる 研究が必要になると思われる.

\section{4. 結 言}

ビッカース圧子を圧入することにより予き裂を導入した ガス圧焼結窒化ケイ素試験片の室温大気中におけるき裂進 展挙動を調査した結果, 以下の結論を得た。

（1）繰り返し荷重下及び静荷重下共に，き裂進展曲線 （繰り返し数あるいは時間とき裂長さの関係）を求めるこ とができた。

（2）上記のき裂進展曲線から求めた $K_{\mathrm{I}}-V$ 線図はラプ チャ一試験により求めた $S-T$ 線図と比較的良く対応して おり，き裂進展速度の測定は短時間で，かつ少数の試験片 により疲労寿命を予測する有効な手段となる可能性があ る.

（3）静荷重下ではき裂が停留した試料にそれよりも低 い応力で繰り返し荷重を負荷すると, き裂が進展すること
が観察され，明らかに繰り返しによるき裂進展の加速が生 じることが確認された。

（4）繰り返し荷重下, 静荷重下のいずれの場合も粒子 架橋を伴った粒界破壊が主であるが，静荷重下で粒子架橋 が観察された試料に繰り返し荷重を与えると粒子架橋の部 分が破壊されていることが分かった。

（5）以上の結果から，静荷重下と繰り返し荷重下でき 裂進展速度が異なるのは, 静荷重下ではき裂の遮蔽に作用 していた粒子架橋が, 繰り返し荷重下では破壊されその遮 蔽効果が低下することに起因すると考えられた。

(1990年 9 月第 2 回秋季シンポジウム発表)

$$
\text { 文 献 }
$$

1）服部善憲，機能材料，9，32-42 (1989)。

2) Y. Tajima, K. Urashima, M. Watanabe and Y. Matsuo, "Ceramic Materials and Components for Engines", The Am. Ceram. Soc., Inc. (1988) pp. 719-28.

3）大塚昭夫，石原泰之，東郷敬一郎，昭和63年日本材料学会 疲労シンポジウム予稿集 (1988).

4）桝田昌明, 相馬隆雄, 松井 實, 小田 功, セラミックス 論文誌, 96, 277-83 (1988).

5）桝田昌明, 山田直仁, 相馬隆雄, 松井 實, 小田 功, セ ラミックス論文誌, 97, 520-24 (1989)。

6）山内幸彦, 酒井清介, 伊藤 勝, 大司達樹, 兼松 渉, 伊 藤正治, 名古屋工業技術試験所報告, 35, 179-84 (1986).

7) T. Kawakubo and K. Komeya, J. Am. Ceram. Soc., 70, 40005 (1987).

8）山内幸彦, 酒井清介, 伊藤 勝, 大司達樹, 兼松 渉, 伊 藤正治，名古屋工業技術試験所報告，35, 325-30 (1986).

9）岸本秀弘, 上野 明, 河本 洋, 材料, 36, 1122-27 (1987).

10）岸本秀弘, 上野 明, 河本 洋, 藤井康義, 材料, 38 , 1212-17 (1989).

11）上野 明, 岸本秀弘, 河本 洋, 森 英俊, 第 5 回破壊力 学シンポジウム講演論文集 (1989) pp. 6-10.

12）岸本秀弘, 上野 明, 河本 洋, 藤井康義, 朝倉幹男, 第 5 回破壊力学シンポジウム講演論文集 (1989) pp. 16-20.

13) S. Horibe, J. Mater. Sci. Lett., 7, 725-27 (1988).

14）丹羽倫規, 浦島和浩, 多島 容, 渡辺正一, セラミックス 論文誌, 99, 296-99 (1991).

15) G. R. Anstis, P. Chantikul, B. R. Lawn and D. B. Marshall, J. Am. Ceram. Soc., 64, 533-38 (1981).

16) I. S. Raju and I. C. Newman, Jr., Engng. Fract. Mech., 11, 817-29 (1979).

17）小林英男，川久保 隆，日本金属学会会報，27，757-65 (1988).

18）堀部 進，鉄と鋼，第75年第 4 号（1989）pp. 578-86.

19) Y. Maniette, M. Inagaki and M. Sakai, J. Europ. Ceram. Soc., 7, 255-63 (1991). 